の様に及ぼすか？ 答 水晶体を考慮する為マルチリーフを使用し て15\%線量ダウンを行っている.演題69はモジュレックス装置を用い て 3 種の不均質補正法について相互比較を行い臨床応用の問題点を 検討した報告で Power-low-TAR 法が最適であるとの報告である. 演題71は側方向からの不整形照射野でシャドウトレイ板の穴が線量 分布に及ぼす影響について検討した報告である.演題72は全身照射に おける平坦度, 補正係数, 補償材の減衰率について検討したもので肺 線量を $35 \%$ ダウンさせる方法についての報告である. 間質性肺炎防止 の為肺線量を $35 \%$ ダウンさせ体位変換時における体軸中心が $3 \mathrm{~cm}$ ずれるだけで 5 〜 Rad の誤差が出るとの報告も無視できない数値 である. 照射野外表面線量を $30 \%$ から $15 \%$ に減少させ治療の精度, 効 率を上げる為にもマルチリーフは是非必要であろう. 又, 線量分布の 補正を行い適正な線量を照射することこそ放射線治療の原点ではな かろうか？ 質問 (三村·岡山大) TPR がよく一致しているか？答 距離が変ってもよく一致するのは壁からの散乱線付加が加わりその 影響と思う.最后に各演者のご努力に敬意を表すると共に今后のご研 鑚を希望致します。

放射線治療技術 3

座長 山岡信夫（鳥取大学医学部附属病院）

73. 高知医科大学放射線治療システムについて

高知医科大学附属病院

山形憲生・横田典和・森尾一夫・遠山坦彦

高知医科大学医学部 小川恭弘

治療装置更新により RT/Marker（横河), Modulex (CMS), LINAC (ML-15MDX : 三菱) を導入した。これらをオンラインで結 ぶ事により適切な治療計画, 記録管理, 照射を行えるようになった。

RT/Marker はCT 画像を利用する事により 3 次元的治療計画を 可能にしたもので, 病変を正確に把握する事ができ最適な治療計画を 行う事ができる. LINAC に付属の照合記録装置に治療パラメータを 転送し，患者 ID を入力する事によりセットアップと照合を行い，記 録, 管理を行えるようになった. Modulex は RT/Marker の補足線量 分布, MU 値等の計算に使用している.

74. CT シミュレーターを中心とした放射線治療システムについて 倉敷中央病院

○武政 洋・清川文秋・岡本昌之・片岡伸子・上田良作

〔目的〕島津 CTシミュレータ CTS - 20 と治療計画装置 MODULEX. 三菱マルチリーフ付きリニアック ML-15MDX のオン ライン化を行った放射線治療システムの使用経験について報告した。

〔まとめ〕 (1) CT 画像にて腫瘍の位置を正確に把握し, 短時間で正 確な最適治療計画が行え，特に斜入や接線照射に有用である，(2)マル チリーフを用いて不整形照射野の自動設定ができる. (3)Cアーム型レ ーザー投光器によりアイソセンタを示す 3 点及び任意の照射野形状 を投光できる.(4)オンライン化により CT 画像をMODULEX に転送 し線量分布や不均質補正を行うた MU 計算が短時間で簡単に可能に なった.

75. CT シミュレータの精度について

倉敷中央病院

○清川文秋・武政 洋・岡本昌之・片岡伸子・上田良作

島津製 CT シミュレータ CTS-20/X のスキャン精度, プランニン グ精度，投光精度について検討した。 (1)天板たわみ，天板移動精度， スライス厚, CT 值とも良好であった。画像再構成は約 $2 \mathrm{~mm}$ 小さく なったが, 計測時のウインドレベルによるものと思われる. (2)プラン ニング精度はビーズ中に球, 立方体, 卵, バナナを入れて $10 \mathrm{~mm}$ スラ イスにてプランニングを行い LGにて誤差を湘定した. X，Y 軸に比

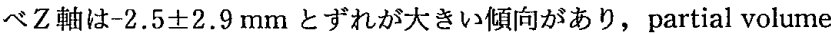
が少なく紐かくターゲットを決定できる $5 \mathrm{~mm}$ スライスの方がよい と思われた. (3)Cアーム型レーザー投光器の投光精度は最大暿差 2 $\mathrm{mm}$ で良好であったが，定期的な保守管理が必要と思われた。

\section{6. 放射線治療照合画像の画買改善}

川崎医科大学附属病院

○滿田典子・沼口健治・長瀬尚已・古城 剛・成廣直正 吉田耕治・浮田智子・日地啓夫

川崎医療短期大学 松宮 昭

〔目的〕放射線治療昭合画像における画質改善のアプローチとし
て, 比較的簡単な方法で高エネルギーX線の線筫低下を試みたので報 告する.【万法] 線質低下法としては, (1)ターゲット.は厚さを隇らし 低原子番号物質へ(2)フラットニングフィルターの除去である. (1), (2) を簡便に達成するために，4 MeV 電子線モードでステンレス製スキ ヤタリングフォイルをターダットに代用した。結果〕深部率曲線に おいて, 従来の線質に比べて, ライナックから得られる高エネルギー X線の線質低下を認めた. ライナックグラフィーにおいては, 画質改 善の可能性が示唆された。

\section{座長集約}

演題73，74は, RT/Marker, CTS-20をそれぞれオンラインした放 射線治療システムの紹介と使用経験を, 演題75は, CTS-20 の精度に ついて, 演題76は, 照合画像の画質改善についての発表であった. CT シミュレータは, 約 $40 \%$ の使用率で, 部位的制限, 再構成画像の解像 度, 装置の操作性が問題点として挙げられた。今後の改良が望まれ る. CT シミュレータによる誤差は，セーフティーマージンを考慮す る.また，定期的な保守管理により高い再現性を確保する必要があ る. 照合画像は, 照射野形状が複雑になるほど良い画質が望まれるの で，今後の研究を期待したい。な扔，この分野は関心が高く質問も多 数あった.

MRI 1

77. Fast Spin Echo 法の使用経験

座長 山本一雄（津山中央病院）

愛媛大学医学部附属病院

○上田幸介・大元謙二・渡部真二・川上壽昭

〔目的〕 GE 社製 SIGNA Advantage (1.5 T) に導入された fast spin echo (FSE) 法はSE 法と比較して最大 $1 / 16$ の撮像時間で画像を 得ることができる. 更に512マトリクスによる高分解能画像が短時間 で撮像可能となった. 今回我々は, FSE 法の特性と臨床応用について 検討を加えた。【方法】 臨床画像にて従来より使用されてきたSE 法 及び GFE 法との比較検討を行った。 またファントムにて分解能, SNR の比較を行った。結果〕 FSE 法は撮像方法や画像コントラス トが SE 法と若干異なる部分がある。しかし顕部，春椎領域において は512マトリクスを併用することにより、多少 S/N の低下が認められ るものの, 従来にない高コントラスト, 高分解能画像が短時間で得ら れ臨床的に極めて有用と考える。

\section{IR Prepared FAST GRASS を用いた T1 測定} 広島総合病院

○山口裕之・上中 治・中村哲之・本山貴志・海老谷京子 藤川光一

〔目的〕IR 型の preparation pulse を付加した FAST GRASS と 通常の IR 法によりファントム及び正常者の頭部, 腹部を撮影し算出 された T1 值を比較することにより IRGによる T1 值測定の可能性 を確認した。 また，シミュレーションを行いファントム実験の妥当性 を確認した。

【結果】 IR 法で得られた T1 值と IRG で得られた T1 值は近似し ておりファントム実験及び人体各組織を対象に行った検討において も両者は良好な相関を示した.シミュレーションの結果はファントム 実験の良好な結果を裹付けるものであった。 以上より本法は IR 法に よるT1 值測定に代わりうるものと判断された。

\section{FAST SPGRによる multislice dynamic MRI の有用性} 広島総合病院

○本山貴志・中村兽之・山口裕之・海老谷京子・上中 浩 藤川光一

我々は肝細胞癌20症例に対し，FAST SPGRによる multi slice dynamic MRI（以下 MS-dyMRI）を実施し，その所見を，CT，扔 よび conventional MRI（以下 cMRI）の所見と比較することにより その有用性を検討した。

cMRI およびCT $に$ MS-dyMRI を加えることによって, 検出病変 数はそれぞれ，10例および 8 例増加した。 また cMRI やCT で HCC としての特徵的所見が得られなかった各 6 例において, MS-dyMRI ではいずれも早期濃染や被膜濃染が描出され，質的診断が可能となっ た. 以上より MS-dyMRI は病変検出能, 質的診断能いずれにおいて も，cMRIやCT を上回ると考えられた，今後，肝の high risk case にたいする screening においても積極的に実施する予定である。 